\title{
尹USGS
}

\section{PETROLEUM SYSTEM OF THE GIPPSLAND BASIN, AUSTRALIA}

by Michele G. Bishop ${ }^{1}$

Open-File Report 99-50-Q

2000

U.S. Geological Survey E-Bulletin

2000

This report is preliminary and has not been reviewed for conformity with the U. S.

Geological Survey editorial standards or with the North American Stratigraphic Code.

Any use of trade names is for descriptive purposes only and does not imply endorsements by the U. S. government.

\section{U. S. DEPARTMENT OF THE INTERIOR \\ U. S. GEOLOGICAL SURVEY}

${ }^{1}$ Consultant, Wyoming PG-783, contracted to USGS, Denver, Colorado 


\section{FOREWORD}

This report was prepared as part of the World Energy Project of the U.S. Geological Survey. In the project, the world was divided into 8 regions and 937 geologic provinces. The provinces have been ranked according to the discovered oil and gas volumes within each (Klett and others, 1997). Then, 76 "priority" provinces (exclusive of the U.S. and chosen for their high ranking) and 26 "boutique" provinces (exclusive of the U.S. and chosen for their anticipated petroleum richness or special regional economic importance) were selected for appraisal of oil and gas resources. The petroleum geology of these priority and boutique provinces is described in this series of reports.

The purpose of this effort is to aid in assessing the quantities of oil, gas, and natural gas liquids that have the potential to be added to reserves within the next 30 years. These volumes either reside in undiscovered fields whose sizes exceed the stated minimumfield-size cutoff value for the assessment unit (variable, but must be at least 1 million barrels of oil equivalent) or occur as reserve growth of fields already discovered.

The total petroleum system constitutes the basic geologic unit of the oil and gas assessment. The total petroleum system includes all genetically related petroleum that occurs in shows and accumulations (discovered and undiscovered) that has been generated by a pod or by closely related pods of mature source rock and which exists within a limited mappable geologic space, together with the essential mappable geologic elements (source, reservoir, seal, and overburden rocks) that control the fundamental processes of generation, expulsion, migration, entrapment, and preservation of petroleum. 
The minimum petroleum system is that part of a total petroleum system encompassing discovered shows and accumulations together with the geologic space in which the various essential elements have been proved by these discoveries.

An assessment unit is a mappable part of a total petroleum system in which discovered and undiscovered fields constitute a single relatively homogenous population such that the chosen methodology of resource assessment based on estimation of the number and sizes of undiscovered fields is applicable. A total petroleum system might equate to a single assessment unit. If necessary, a total petroleum system may be subdivided into two or more assessment units such that each assessment unit is sufficiently homogeneous in terms of geology, exploration considerations, and risk to assess individually.

A graphical depiction of the elements of the a total petroleum system is provided in the form of an event chart that shows the time of deposition of essential rock units; the time processes, such as trap formation, necessary to the accumulation of hydrocarbons took place; the critical moment in the total petroleum system; and the preservation time, if any.

A numeric code identifies each region, province, total petroleum system, and assessment unit; these codes are uniform throughout the project and will identify the same item in any of the publications. The code is as follows:

\section{Example}

Region, single digit $\quad 3$

Province, three digits to the right of region code 3162 
Total Petroleum System, two digits to the right of province code

The codes for the regions and provinces are listed in Klett and others, 1997.

Oil and gas reserves quoted in this report are derived from Petroleum Exploration and Production database (Petroconsultants, 1996) and other area reports from Petroconsultants, Inc., unless otherwise noted.

Fields, for the purpose of this report, include producing fields, discoveries (suspended and abandoned) and shows as defined by Petroconsultants (1996) and may consist of a single well with no production.

Figure(s) in this report that show boundaries of the total petroleum system(s), assessment units, and pods of active source rocks were compiled using geographic information system (GIS) software. Political boundaries and cartographic representations were taken, with permission, from Environmental Systems Research Institute's ArcWorld 1:3 million digital coverage (1992), have no political significance, and are displayed for general reference only. Oil and gas field centerpoints, shown on this (these) figure(s), are reproduced, with permission, from Petroconsultants, 1996.

\section{REFERENCES}

Environmental Systems Research Institute Inc., 1992, ArcWorld 1:3M digital database:

Environmental Systems Research Institute, Inc. (ESRI), available from ESRI, Redlands, CA, scale: 1:3,000,000. 
Klett, T.R., Ahlbrandt, T. A., Schmoker, J.W., and Dolton, G. L., 1997, Ranking of the world's oil and gas provinces by known petroleum volumes: U.S. Geological Survey Open-File Report 97-463, one CD-ROM.

Petroconsultants, 1996, Petroleum Exploration and Production Database: Petroconsultants, Inc., P.O. Box 740619, 6600 Sands Point Drive, Houston TX 77274-0619, USA or Petroconsultants, Inc., P.O. Box 152, 24 Chemin de la Mairie, 1258 Perly, Geneva. 


\begin{abstract}
The Gippsland Basin Province 3930, located on the southeastern coast of Australia, is formed from two successive failed rifts that developed into a passive margin during the Cretaceous. Formation of this basin is related to the break up of Gondwana, which resulted in the separation of Antarctica from Australia, and the separation of the New Zealand and Lord Howe Rise continental crust from Australia. Coals and coaly shales of Late Cretaceous through Eocene age are the source rocks for oil and gas that accumulated predominantly in anticlinal traps. The basin was Australia's major producing basin until 1996 when daily oil/condensate production from the North West Shelf surpassed it.
\end{abstract}

\title{
INTRODUCTION
}

One Total Petroleum System (TPS), Latrobe 393001, is described in the Gippsland Basin Province with one assessment unit, Gippsland 39300101 (Fig. 1). It consists of Upper Cretaceous upper coastal plain coals and coaly shales of the Latrobe Group as the source rock and Upper Cretaceous through Eocene Latrobe Group fluvial, deltaic, and marginal marine sandstones as reservoir rocks (Fig. 2). The available data indicate that the discovered reserves in the Gippsland Basin are derived from these terrestrial coals and coaly shales (Bradshaw and others, 1998; Rahmanian and others, 1990; Howes, 1997; Fielding, 1992; MacGregor, 1994; Hocking, 1976). Nearly three quarters of the estimated discovered recoverable oil and gas reserves are found in anticlines, domes, and rollover traps (Petroconsultants, 1996). Almost $85 \%$ of the 
volume of reserves is in reservoir sandstones of the Latrobe Group (Petroconsultants, 1996).

The underlying and adjacent Strzelecki (Lower Cretaceous) and Golden Beach (Lower and Upper Cretaceous, also known as the lower Latrobe) Groups (Fig. 2) may have contributed hydrocarbons to overlying accumulations and adjacent accumulations where vertical and lateral out-of-basin migration paths are considered. Recent work describing the source-rock potential, reservoir quality, and trap preservation of Strzelecki and Golden Beach strata includes Mehin and Bock (1998) and Partridge (1996). These strata will be described here, although, not developed into petroleum systems at this time.

The Gippsland Basin has been a significant source of oil and gas in Australia since offshore production began there in 1969. Reserve estimates published by McPhee (1976) listed estimated recoverable reserves of 1,972 million barrels oil (MMBO), 174 million barrels condensate (MMBCond), 469 million barrels liquid petroleum gas (MMBLPG), and 222 billion cubic meters gas (Bm3) (7,840 billion cubic feet gas (BCFG)). It is interesting to note that since offshore production began in 1969 the Gippsland Basin has produced 3,446.5 MMBO and 4,779.5 BCFG with remaining reserves totaling 629.9 MMBO and 4,827.8 BCFG (Mehin and Bock, 1998). Revived exploration efforts for and renewed exploitation of gas reserves to serve growing markets in New South Wales, Victoria, and Tasmania would be facilitated by the planned new gas pipeline from Victoria to Sydney in New South Wales (Hart's E \& P, 1999). 


\section{PROVINCE GEOLOGY}

The USGS Province 3930 includes the Gippsland Basin, both onshore and offshore, and portions of the pre-Tertiary platform to the south and northeast totaling 8,1095 square kilometers $\left(\mathrm{km}^{2}\right)$ (Fig. 3). The province extends from south of Melbourne, Victoria, southeast across Flinders Island to east of Tasmania and northeast to offshore of Cape Howe at the border with New South Wales (Fig. 1). The Gippsland Basin covers an onshore and offshore area of Victoria that is approximately 4,600 km² (Mehin and Bock, 1998). More than $70 \%$ of the basin lies offshore. The offshore producing area of the province is in the waters of Victoria. The southern portion of the province is in waters of Tasmania, and the northeastern corner is in waters of New South Wales (Fig. 1). The basin averages $300 \mathrm{~km}$ in width and contains sediments more than $8 \mathrm{~km}$ thick (Mehin and Bock, 1998).

\section{TECTONICS}

During Late Jurassic to Early Cretaceous time, the Gippsland Basin was part of a rift complex several hundred kilometers wide that formed between the Australian Plate/Tasman Fold Belt and the Antarctic Plate (Rahmanian and others, 1990; Etheridge and others, 1987; Falvey and Mutter, 1981). This Bassian Rift System included three major components from west to east, the Otway, Bass and Gippsland Basins (Mehin and Bock, 1998). By mid-Late Cretaceous time, this rift complex was the site of the separation of Gondwana along what is now the southern margin of Australia (Rahmanian and others, 1990). Although the Late Jurassic rift complex was located between Australia and Tasmania, Late Cretaceous separation and creation of ocean crust occurred 
to the west of Tasmania (Rahmanian and others, 1990; Mehin and Bock, 1998).

Separation and creation of ocean crust in the latest Cretaceous Tasman Rift event progressed along the eastern side of Tasmania and Australia, separating (1) the Australian Plate from the continental crust of New Zealand/Lord Howe Rise, and (2) the Antarctic Plate from continental crust of the Campbell Plateau (Rahmanian and others, 1990), leaving Tasmania attached to Australia. Regional extension and development of syn-rift troughs and volcanism, beginning at approximately 96 million years ago (Ma), occurred in the Gippsland Basin and began a history separate from the other two components of the earlier Bassian Rift System (Mehin and Bock, 1998; Hill and others, 1995; Lowry and Longley, 1991).

\section{STRUCTURE}

The Gippsland Basin trends east-west and is comprised of a deep central depression symmetrically bounded by faulted terraces and stable platforms on the north and south. The Northern, or Lakes Entrance Platform, is bounded on the south by the Lake Wellington fault and the Southern Platform is bounded on the north by the Foster fault system (Figs. 3 and 4). Sediments of the basin crop out in the west and are deeply buried offshore and to the east. The deep Central Depression (Central Deep) continues onshore as the Seaspray Depression (Figs. 3 and 4). It lies between the Rosedale fault, which defines the southern edge of the Northern Strzelecki Terrace, and the Darriman fault, which defines the northern edge of the Southern Strzelecki Terrace (Fig. 3).

Normal faults trending northwest to southeast, of Early Cretaceous to Early Eocene age, characterize the central depression (Fig. 3) (Ozimic and others, 1987). The 
major fields are located in anticlinal traps formed by compressional events and shear faults associated with the opening of the Tasman Sea (Fig. 1). Late Eocene to Early Oligocene and Late Miocene age anticlines are generally oriented southwest to northeast and are located in the central depression and on the northern terrace (Ozimic and others, 1987).

A variety of Paleozoic rocks underlies the Gippsland Basin Province. Much of the area was covered by glaciers that came from Antarctica, located to the southwest, in Early Permian time (Bowen and Thomas, 1976). The Strzelecki Group is described at various locations as unconformably overlying Permian sediments, Upper Devonian rocks, Lower Devonian rocks, Devonian granite, and in other locations as faulted against Lower Devonian or Silurian beds (Douglas, 1976). At one onshore well location on the Northern Strzelecki Terrace near the Lake Wellington fault, a post-glacial, marginal marine to deltaic Lower Permian sandstone, shale, and siltstone section more than $180 \mathrm{~m}$ thick was described overlying folded Ordovician rocks (Bowen and Thomas, 1976; Douglas, 1976). Both crystalline basement and metamorphic basement have been described in onshore wells on the Lakes Entrance Platform. Extrusive igneous rocks were reported in the most southerly well in the province, which is located on the Southern Platform offshore Flinders Island. Jurassic age rocks were reported in wells located onshore on the Southern Strzelecki Terrace in the westernmost area of the province, and on the Northern Strzelecki Terrace near Lake Wellington (Petroconsultants, 1996). 


\section{DEPOSITION}

\section{Strzelecki Group}

The Gippsland Basin includes Lower Cretaceous continental and lacustrine clastics deposited in an extensional rift trend that extended along the modern southern margin of Australia and which had formed between the then connected Australia Plate and the Antarctic Plate of Gondwana. These deposits are known as the Otway Group in the Otway Basin area of the southern margin, which is located northwest of the Bass Basin Province 3907 (Fig. 1), and the Strzelecki Group in the Gippsland Basin.

The known extent of the nonmarine Strzelecki Group (Korumburra Group, near offshore; Koonwarra Fish Beds and Tyers Group, Rhyll Arkose, onshore) (Douglas, 1976), is roughly between the Foster fault system to the south and the Lake Wellington fault to the north and from the Gippsland Highlands east, to where the strata are interpreted from seismic data (Figs. 3 and 4) (DPIE, 1998; Mehin and Bock, 1998; Douglas, 1976). The group crops out onshore in uplifted fault blocks of the Gippsland Highlands (Strzelecki Ranges) and northeast of Yallourn, with exposures covering more than $3,900 \mathrm{~km}^{2}$ (Douglas, 1976).

The Strzelecki Group is of Early Cretaceous age and was deposited in an eastwest trending rift basin complex that began as a pre-breakup depression and failed rift approximately $130 \mathrm{Ma}$ (Mehin and Bock, 1998). The rift complex was the eastern extension of the Otway and Bass Basins, which also received sediments of similar composition and depositional environment beginning in the Late Jurassic (Bradshaw, 1993). The correlative group in the Otway Basin is a good coaly source rock that sources gas in at least two fields (M. Woollands, written personal commun., 1999). 
Exploration in the Gippsland Basin has thus far considered the nonmarine Strzelecki Group to be economic basement and unprospective (M. Woollands, written personal commun., 1999), but new research is currently reconsidering its potential (Mehin and Bock, 1998). The group occurs in the subsurface to the north and south of the productive Upper Cretaceous trend (discussed below), on the Northern Strzelecki Terrace and the Southern Strzelecki Terrace (Douglas, 1976) but has not been explored under most of the productive trend in the offshore Central Depression because of drilling depths that generally exceed 5-7 km (Fig. 4).

Thickness of the Strzelecki Group generally ranges from a few hundred meters to more than 2,600 m (Douglas, 1976, McPhee, 1976) but estimated thickness in some areas is as much as $6,000 \mathrm{~m}$ (McPhee, 1976). The group is composed of nonmarine greywackes, mudstones, sandstones, conglomerates, coals, and volcanoclastics (Douglas, 1976; Mehin and Bock, 1998). Depositional environments include lakes, swamps and floodplains.

Subdivision and correlation of units within the group have proven difficult, although outcrops were described as early as 1856 in connection with evaluations of coal resources (Douglas, 1976; Gloe, 1976; Knight, 1976). The lower portion of the Strzelecki Group consists of the Lower Neocomian Tyers Conglomerate and finer grained equivalents deposited on a Paleozoic age erosional surface on granites and metamorphics (Mehin and Bock, 1998). The upper Strzelecki Group consists of coals, shales, siltstones, and volcanic sandstones of the Wonthaggi Formation (Mehin and Bock, 1998). Medium- to fine-grained feldspathic sandstones make up more than $40 \%$ of the outcrop area (Douglas, 1976). Lenticular and cross-bedded sandstones $60 \mathrm{~m}$ thick are 
common, and sandstone sequences are as much as $140 \mathrm{~m}$ thick in some outcrops (Douglas, 1976). The sandstone contains oligoclase, orthoclase, perthite, microcline, quartz, biotite, hornblende, andesite and calcite (Douglas, 1976). Mudstone beds are as much as $130 \mathrm{~m}$ thick and are mineralogically similar to the sandstone except that the mudstone is dominantly potassic whereas the sandstone is dominantly sodic (Douglas, 1976).

Potential sandstone reservoirs within examined intervals of the Strzelecki Group are of poor quality (McPhee, 1976), having poor porosity due to diagenetic clays and alteration of volcanic rock fragments. Better reservoirs and good exploration targets may be defined with an exploration program aimed specifically at rift-basin style stratigraphy and traps. The source-rock potential of the coals and lacustrine shales in the group is poorly known (Mehin and Bock, 1998), although the subsurface edges of the depositional extent of the group appear to be in the oil window along the northern and southern terraces (Ozimic and others, 1987), and methane occurrences at the margins of the basin may have been sourced by the Strzelecki Group (Mebberson, 1989).

The Lower Cretaceous Strzelecki Group was deformed and eroded by a $96 \mathrm{Ma}$ event that may have included compressional realignments of the breakup of Gondwana (Fig. 2) (Duff and others, 1991). Strata of latest Early Cretaceous through Cenomanian age are not present. The overlying Late Cretaceous Central Depression, developed between the northern and southern terraces, has buried the Strzelecki Group offshore to depths of more than $8 \mathrm{~km}$ (Ozimic and others, 1987) and currently into the overmature range. 


\section{Golden Beach Group}

The Golden Beach Formation of the Latrobe Group was described by T. R. Haskell in 1972 from the Golden Beach 1A well drilled in 1967 (Lowry, 1987). This formation was described as continental sandstone and shale overlying the Strzelecki Group and underlying the unconformity within the $N$. senectus palynomorph zone (Lowry, 1987). Since 1990 the lower Latrobe has been described in the literature as the Golden Beach Group (Fig. 2). The Golden Beach Group was deposited in a rapidly subsiding, extensional rift trend of a slightly different orientation that overprinted and formed within the trend that existed during deposition of the Strzelecki Group. The rift was occupied by deep-water lakes and, following the breakup of the southern Australian margin, was flooded by marine waters (Duff and others, 1991; Partridge, 1996). Where the Golden Beach Group is present, it rests unconformably on the Strzelecki Group (Fig. 4). Mineralogy changes from volcanogenic in the Strzelecki Group to quartzose in the Golden Beach Group (Mehin and Bock, 1998).

The Golden Beach Group is divided into the Turonian age Emperor sub-group and the Santonian to Campanian age Golden Beach sub-group (also referred to as the Golden Beach Formation or Chimera Sandstone) (Partridge, 1996; Mehin and Bock, 1998; DPIE, 1998). An unconformity of Turonian to Santonian age (duration of 5 million years (m.y.)) separates the two sub-groups (Fig. 2) (Partridge, 1996; DPIE, 1998).

The Kipper Shale of the Emperor sub-group was deposited in lakes (Partridge, 1996). This lake complex is described as deep and persistent through time (perhaps as long as 3 m.y.) with lake surface areas estimated at $5,000 \mathrm{~km}^{2}$ (Partridge, 1996). Thick sections of lacustrine shale have been drilled (Moore and others, 1992). In the Manta and 
Basker fields area, the lower Latrobe Group is described as alluvial sandstones with interspersed volcanic flows of andesitic to basaltic composition (Clark and Thomas, 1988).

More than $600 \mathrm{~m}$ of Golden Beach Group is preserved in the Central Depression offshore area, as well as in parts of the adjacent onshore Seaspray Depression (Fig. 3) (Partridge, 1996; Mehin and Bock, 1998). Normal faulting along the Rosedale and Darriman faults truncated and then confined deposition of the group to the rapidly subsiding depression between the Northern and Southern Strzelecki Terraces (Mehin and Bock, 1998). Development of these terraces coincides with opening of the Tasman Sea beginning at $80 \mathrm{Ma}$ (Rahmanian and others, 1990). The first marine influences in the Gippsland Basin occurred in middle Santonian time during deposition of the Golden Beach sub-group (Partridge, 1996) and the transgressions are interpreted by some to have come from the southwest (Megallaa, 1993). The Campanian rocks are described as sandstones and overbank shales that were deposited across a coastal plain by a meandering river system with north to south flow (Clark and Thomas, 1988).

An unconformity developed on top of the sediments of the Golden Beach subgroup approximately $80 \mathrm{Ma}$, with subsequent latest Campanian volcanics resting unconformably on this surface (DPIE, 1998; Partridge, 1996). The Golden Beach and Strzelecki were tilted to the east-southeast and eroded (Mehin and Bock, 1998). This Campanian tectonism and associated volcanism accounts for major displacements on intra-Golden Beach sub-group faults, and for the extrusion of the surface basalt flow that serves as a seal for gas and oil traps in Golden Beach sandstones at Kipper Field (Fig. 5) (DPIE, 1998; Sloan and others, 1992). 


\section{Latrobe Group}

Late Cretaceous (Campanian) tectonism, which ended deposition of the Golden Beach Group, resulted in (1) the separation of Gippsland Basin from the Bass Basin by the Bassian Rise, and (2) the emergence of the Southern Platform (Duff and others 1991; Megallaa, 1993) (Fig. 3). Paleogeographic maps portray the basin during latest Cretaceous Latrobe deposition as a gulf facing the opening Tasman Sea to the east with two structurally controlled lows traversing the Gippsland Rise (Fig. 3) (Fielding, 1992; Megallaa, 1993). The Gippsland Rise is shown as sometimes emergent with circulation from the sea through the structural lows (Megallaa, 1993). By the end of the Cretaceous, the offshore Gippsland Basin began to subside as a marginal sag (DPIE, 1998). Compression became the dominant tectonic style from Eocene to Miocene time during the passive margin stage related to the continuing opening of the Tasman Sea (Megallaa, 1993).

The Latrobe Group consists of sandstones, siltstones, mudstones, shales, coals, and volcanics that were deposited in alluvial, shoreline and shallow to shelf marine settings and deep-water low-stand cut-and-fill channels; the thickness of the sequence totals more than 4,500 m within the Central and Seaspray depressions (McPhee, 1976; Featherstone and others, 1991). The Cretaceous to Paleocene portion of the Latrobe Group is interpreted to have been sand-rich coastal plain and barrier sediments deposited in an aggradational setting (Fielding, 1992). Multiple transgressions and regressions of coastal plain and barrier settings are recorded in the Late Paleocene to Eocene portion of the group (Fielding, 1992). Paleoshorelines trended generally southwest to northeast and were located, for the most part, between Mackerel and Blackback fields (Fig. 5) 
(Rahmanian and others, 1990; Fielding, 1992; Megallaa, 1993; Moore and others, 1992; Gross, 1993). These paleogeographic reconstructions show a wide zone of migrating shoreline environments backed by an extensive coastal plain surrounded by alluvial and fluvial settings within the confines of the faulted basin during deposition of the lower Latrobe section (Douglas, 1976; Fielding, 1992). Clastic sediments were sourced from the Australian continent to the north and the Bassian Rise and Southern Platform to the southwest and south of the basin as well as from the west along the basin axis. Westward marine transgressions and eastward regressions of the Tasman Sea alternated with periods of continental clastic sedimentation (Douglas, 1976; Fielding, 1992), but no major deltaic sequences have been described. These sediments progressively onlapped the terraces to the north and south and onlapped to the west during Late Cretaceous through Oligocene time. Onshore in the northwest area, the Strzelecki Group is overlain by a series of Latrobe Group formations: an Eocene or Paleocene sandstone, Thorpdale Volcanics consisting of Eocene basaltic lavas, Oligocene to Miocene age nonmarine clastics, and Latrobe Valley Coal Measures (Mehin and Bock, 1998). In the onshore Seaspray Depression, Latrobe Group rocks are described as Upper Cretaceous to Oligocene non-marine sandstones, siltstones, mudstones, coals and shales (Mehin and Bock, 1998). The Maastrichtian-Paleocene upper Latrobe Group rocks in the offshore area are described as having been deposited in coastal plain, shoreline, and nearshore settings featuring a series of thick barrier bar facies (Clark and Thomas, 1988). Eocene paleogeographic reconstructions show as much as a $40 \mathrm{~km}$ wide coastal barrier fronted by wide shallow marine environments and backed by a coastal plain that was no longer confined by the faulted basin (Fielding, 1992). 
Tectonic uplift of the northeastern basin in Eocene time along with sea level lowstands, caused deep submarine channeling into strata of the Latrobe Group and into anticlines involving these rocks (Douglas, 1976; DPIE, 1998). Three of these erosional unconformities occur at the Blackback field anticline (Gross, 1993). Major channeling events include a Maastrichtian event, the early Eocene Tuna/Flounder channel that was filled by the Flounder Formation and the Eocene Marlin Channel filled by the Turrum Formation (Fig. 2) (Douglas, 1976; Moore and others, 1992). The current Bass Channel, or Bass Canyon, occupies the southern structural passage across the Gippsland Rise and erodes into the Latrobe Group. The Gurnard Formation, where present, is generally placed at the top of the Latrobe Group and consists of offshore (Eocene) to onshore (Oligocene) glauconitic sandy siltstone (DPIE, 1998). Further onshore in the Latrobe Valley, deposition of the Latrobe Valley Coal Measures continued through the Pleistocene (Mehin and Bock, 1998; McPhee, 1976; DPIE, 1998).

Another tectonic event formed an extensive erosion surface on top of the Latrobe Group 50 Ma (Duff and others, 1991). The overlying Seaspray Group consists of shales and marls that are the regional seal for the majority of fields in the Gippsland Basin (Fig. 2). Unconformities and at least two mid-Miocene channel cut-and-fill events are present within the Seaspray Group. Compression during Seaspray time is represented by gentle unfaulted anticlines in contrast to older faulted anticlines (Duff and others, 1991).

\section{HISTORY OF PETROLEUM EXPLORATION}

Oil and gas were discovered onshore at Lake Bunga No. 1 in 1924 (Fig. 5)

(Ozimic and others, 1987). This discovery, near Lakes Entrance, started exploration 
interest in the Gippsland Basin. Cumulative production to 1956 of 10,000 barrels of biodegraded, heavy crude oil from an Oligocene sandstone in the onshore Lakes Entrance Field was overshadowed by later activity in the offshore areas. In December of 1964 the drill ship Glomar III began exploration in offshore Gippsland Basin drilling Esso Gippsland Shelf No. 1, in what is now known as Barracouta Field (Fig. 5). Gas production from Barracouta began in early 1969 from Late Eocene Latrobe Group clastic reservoirs in a faulted anticline. Oil was also discovered and later produced from the same field (Ozimic and others, 1987).

\section{PETROLEUM OCCURRENCE}

Gippsland Basin gas fields are located generally in the west-central and northcentral areas (the large Barracouta, Bream, Snapper, and Marlin Fields), and oil fields are located in the east-central and west areas (Fig. 5) (the large Cobia-Halibut, Fortescue, Kingfish, Mackerel and Blackback Fields). This distribution is considered to be a result of local subsidence combined with general heatflow producing areas where the source rock is overmature and generating gas, and other areas where it is mature and generating oil (Mebberson, 1989; Rahmanian and others, 1990; Moore and others, 1992). This distribution is further influenced by local versus areal hydrocarbon drainage areas and migration paths (Moore and others, 1992). Figure 5 shows a generalized summary of the areas and stages of maturation.

There are three major stratigraphic targets that have proved successful in exploration for hydrocarbons, (1) Top Latrobe, (2) intra-Latrobe, and (3) pre-Latrobe. The largest fields and approximately $85 \%$ of the total discovered reserves are found in 
Latrobe Group reservoirs (Petroconsultants, 1996). Fields also occur in strata younger that the Top Latrobe such as Lakes Entrance Field (Ozmic and others, 1987).

The earliest offshore discoveries were in anticlines under the unconformity that defines Top Latrobe. These remain the largest fields discovered in the basin. The Top Latrobe unconformity was developed by a tectonic event $50 \mathrm{Ma}$ (Duff and others, 1991). This unconformity eroded the Latrobe Group strata and anticlines involving the Latrobe Group (Duff and others, 1991; Gross, 1993). Reservoirs beneath the Top Latrobe unconformity vary from Late Cretaceous to Eocene in age (Gross, 1993). The fields immediately below the Top Latrobe are fed by hydrocarbons migrating from large areas of the basin and adjacent synclines (Rahmanian and others, 1990).

Intra-Latrobe fields contain hydrocarbons in Latrobe reservoirs that are not associated with the Top Latrobe unconformity (Clark and Thomas, 1988). These reservoirs are fed by local migration of hydrocarbons within fault blocks and reflect maturation of source rock in a smaller area (Rahmanian and others, 1990; Sloan, 1987).

Pre-Latrobe fields are located on the edges of the basin with reservoirs in the Golden Beach Group (Sloan and others, 1992).

Although Gippsland Basin oils have been attributed to the same source rock, there is considerable variation in chemical composition ranging from very waxy and paraffinic to light and condensate-like (Burns and others 1987; Moore and others, 1992). These differences are attributed to oil being generated at different maturities, low reservoir temperatures, and the presence of a fresh-water wedge that extends from the present shoreline east and south into the basin and to depths of as much as 2,400 m (Fig. 5) (Mebberson, 1989; Moore and others, 1992: Burns and others, 1987). Oils in traps at 
Top Latrobe are not chemically distinct from oils in traps within the Latrobe Group (Clark and Thomas, 1988). Gas generation from a deep overmature source was suggested by Burns and others (1987). Their analysis of six fields showed the carbon isotope composition of methane to range from -31.4 to -41.4 per mil.

Oil gravity ranges from $15.4^{\circ}-64^{\circ} \mathrm{API}$, and sulfur is less than $0.5 \%$ (Burns and others, 1987; Clark and Thomas, 1988; Petroconsultants, 1996). A trend of oil gravity increasing with maturity of the source rocks was shown by Burns and others (1987). Their work also suggested that in Wirrah Field (Fig. 5), accumulations at different reservoir levels were derived from source rocks at different maturities; reserves at 2,633 $\mathrm{m}$ and 2,046 $\mathrm{m}$ were interpreted as being from source rocks in the early mature stage, whereas reserves at 2,195 $\mathrm{m}$ were from source rocks at the peak mature stage.

Published analysis of one onshore field, one nearshore discovery and two offshore fields described the following ranges: methane 82.6-93.3\%; ethane nil-6.8\%; propane + nil-8.6\%; nitrogen nil-18.68\%; oxygen nil-.82\%; $\mathrm{CO}_{2}$ 0.01-2.0\% (McPhee, 1976).

The only production or discovery deemed economic from the onshore portion of the Gippsland Basin is at Lakes Entrance. This field lies on the Northern Platform directly north of the Lake Wellington fault system that defines the southern edge of the platform (Fig. 3 and 5). The reservoir is the Oligocene Lakes Entrance Formation, which occurs in a stratigraphic trap and drape structure overlying paleo-topography (Ozimic and others, 1987). This is a marine sandstone described as poorly cemented, calcareous, glauconitic, and oolitic, with porosity as much as $36 \%$ and permeability averaging 10 millidarcy $(\mathrm{mD})$. The field lies at a depth of approximately $385 \mathrm{~m}$. Oil from this field is 
heavy, API $15.4^{\circ}$ and tarry, and considered to be biodegraded and fresh water washed (Ozimic and others, 1987).

\section{SOURCE ROCK}

The results of analyses of oils and potential source rocks indicate that terrestrial source rocks--coals and lower coastal plain coaly shales--show excellent correlation with the produced oils of the Gippsland Basin (Moore and others, 1992; Philp, 1994). These strata in the Latrobe Group contain total organic carbon contents (TOC) as much as 70 wt $\%$ and hydrocarbon indicies (HI) as high as $400 \mathrm{mg}$ hydrocarbon (HC)/g TOC and are considered to be the source rocks in the basin (Bradshaw and others, 1998; Rahmanian and others, 1990; Howes, 1997; MacGregor, 1994; Hocking, 1976; Fielding, 1992). Marine shales of this group are reported to have TOC values of 1-3 wt $\%$. The average TOC of the Golden Beach Group is 2-3 wt\% (Sloan and others, 1992). The dominantly aggradational setting described by Fielding (1992) during the Cretaceous to Paleocene period of Latrobe deposition may have favored deposition of coal and coaly shale source rocks. Furthermore, McCabe and Shanley (1992) described low-ash coals that are best developed landward of aggradational shorelines and discussed the development of raised peat mires that may have influenced aggradation. One oil sample showed an algal influence in a dominantly terrestrial character (Moore and others, 1992; Marshall, 1989).

The estimated 1,000-m-thick Kipper Shale did not correlate with any of the oils analyzed (Moore and others, 1992). This lacustrine shale measured at the Kipper well averages TOC 2-4 wt $\%$ and is characterized as gas-prone with S2 values below 2 milligrams/gram and HI below $100 \mathrm{mg}$ hydrocarbon (HC)/g TOC (Sloan and others, 
1992). Well intersections at Kipper, Tuna, Emperor, Sunfish and Sole encountered more than $700 \mathrm{~m}$ of lacustrine shale described as lean source rocks with HI of 80-200 mg hydrocarbon (HC)/g TOC (Moore and others, 1992). The poor source-rock quality of this lacustrine shale has been attributed to oxidation of organic matter due to seasonal turnover of the lake waters of this cold climate setting at lat $65^{\circ} \mathrm{S}$ (Partridge, 1996; Moore and others, 1992). This lacustrine shale could be a source for some gas in the Gippsland Basin (Moore and others, 1992).

Possible source rocks in the coaly section of the Strzelecki Group penetrated in onshore wells range from 0.21 to $26.83 \mathrm{wt} \%$ TOC, with vitrinite reflectance in oil $\left(\mathrm{R}_{\mathrm{o}}\right)$ values of 0.35-1.04\% and HI values from 23-179 mg hydrocarbon (HC)/g TOC (Mehin and Bock, 1998).

\section{MATURATION AND MIGRATION}

Peak generation and primary migration occurs at depths of 4-5 km for oil and 5-6 $\mathrm{km}$ for gas (Clark and Thomas 1988). Experimental maturation and sampling from the deep Volador-1 well, to 4,611 m TD, indicate that maturation and peak hydrocarbon generation of the source rocks occurs at $\mathrm{R}_{\mathrm{o}}$ of between 0.92 to $1.0 \%$ (Clark and Thomas, 1988). This is in contrast to maturation of shale source rocks like the Kimmeridge Clay Formation in the North Sea, which reach peak generation at around $\mathrm{R}_{\mathrm{o}} 0.8 \%$ (Clark and Thomas, 1988; Alexander and others, 1991). Calculated maturity from source-rock extracts was compared to vitrinite reflectance measurements by Moore and others (1992) and indicates that discovered oils were generated at maturity levels of $\mathrm{R}_{\mathrm{o}} 1.15-1.30 \%$, and gas from the overmature section at maturity levels of $\mathrm{R}_{\mathrm{o}} 1.25-2.0 \%$. 
Oil and gas generation and expulsion from Golden Beach and lower Latrobe source intervals in the central eastern portion of the Gippsland Basin occurred in Late Cretaceous and Early Paleocene time due to higher heatflow and subsidence of this area prior to formation of trapping structures in Late Eocene to Middle Miocene time (Fig. 4) (Moore and others, 1992; Keall and Smith, 1996). Subsequent to Miocene trap formation, oil has been generated from younger Latrobe source intervals, accounting for the predominance of oil fields in this region (Moore and others, 1992). Gas has been the dominant hydrocarbon generated since trap formation in the area north of Barracouta field, which explains the predominance of gas fields in the north and western portions of the basin (Moore and others, 1992).

Vertical migration of $2 \mathrm{~km}$ or more occurs in the central portions of the Gippsland Basin, and significant lateral migration is cited for accumulation on the Northern Platform (Fig. 4) (Clark and Thomas, 1988). Discovery trends that locate most oil in the middle of the basin and most gas toward the margins are explained by the migration paths and the state of maturity of the immediately adjacent synclinal 'kitchen' (Moore and others, 1992) and the timing of compressional trap formation (Keall and Smith, 1996). Oil fields found on the margins of the basin are thought to tap only oil-mature source rocks within the migration area (Moore and others, 1992). Hydrocarbons from the deepest parts of the basin were expelled during an early phase of generation in the Paleocene, but the main phase of generation has been in the last $20 \mathrm{~m}$. y. (Fig. 6) (Keall and Smith, 1996). Structures in the northwest were not available for early oil migration so these structures have trapped mostly mature gas (Keall and Smith, 1996). Source 
rocks in the southwestern portions of the basin are still in the oil window (Mebberson, 1989; Rahmanian and others, 1990; Keall and Smith, 1996).

There may have been some contribution of hydrocarbons from Strzelecki Group source rocks to the Latrobe petroleum system. Hydrocarbon generation and expulsion modeling from onshore wells in the Seaspray Depression and on the Northern Strzelecki Terrace near Lake Wellington indicate that there was one widespread expulsion event in this area at 115-95 Ma and a second event detected in some wells between 80 and $40 \mathrm{Ma}$ with one area possibly continuing to the present (Mehin and Bock, 1998).

\section{OVERBURDEN ROCK}

Marine sediments of the Lower Oligocene through Miocene Seaspray Group overlie and form a regional seal for the entire offshore and most of the onshore area, with the notable exception of the Latrobe Valley Trough where nonmarine conditions were prevalent and deposition of thick coals continued (Figs. 2 and 4A). This group represents a widespread marine transgression initiated in Oligocene time and reaching maximum in Early to Middle Miocene time, followed by regression beginning in Late Miocene to Early Pliocene time. It is characterized by marine shales, marls, limestones, calcareous claystones, siltstones, and sandstones more than 1,800 m thick, with successive periods of submarine channeling and channel fill (Mehin and Bock, 1998).

The Seaspray Group is divided into three formations: Lakes Entrance, Gippsland Limestone, and Jemmy's Point/Tambo River (Fig. 2) (Mehin and Bock, 1998). The regional seal for the majority of oil and gas fields of the offshore area is the Lakes Entrance Formation (Mehin and Bock, 1998), which consists of sandstone, marl, and limestone deposited unconformably on the Latrobe Group. Marls and calcarenite of the 
Gippsland Limestone Formation represent the maximum marine highstand in the Miocene, and are as thick as $800 \mathrm{~m}$ in the offshore area (Mehin and Bock, 1998). The Miocene to lower Pliocene Jemmy's Point Formation consists of marls, limestone, and shoreline sandstones of the late highstand (Mehin and Bock, 1998).

Onshore, the upper Pliocene Sale Group is nonmarine sandstones and claystones (Mehin and Bock, 1998).

\section{TRAP TYPES}

Compression from Eocene through Early Miocene time resulted in anticlines and fault traps (Figs. 2, 3, 4, and 6) (Mebberson, 1989; Moore and others, 1992; Ozimic and others, 1987). Most of the large accumulations occur immediately below the Top Latrobe unconformity in anticlines eroded and then sealed by the overlying regional Seaspray Group. The traps were in place in the Kingfish Field area at approximately 28 $\mathrm{Ma}$ (Late Oligocene) and in the Barracouta Field area at approximately $22 \mathrm{Ma}$ (Early Miocene) (Mebberson, 1989). At Marlin Field, erosional topography creates a larger closure than the anticline alone (McPhee, 1976). Additional traps within the Latrobe Group are fault traps sealed by the fault or juxtaposed shales (Clark and Thomas 1988). However, favorable juxtaposition is difficult in this fluvial, alluvial, and shoreline sandstone dominated group. Intra-Latrobe Group traps in the Barracouta Field area were in place at approximately $34 \mathrm{Ma}$ (Early Oligocene) (Mebberson, 1989).

Successful fault traps within the Golden Beach Group are formed by lacustrine sandstones juxtaposed against thick lacustrine shale sections. The Kipper discovery appears to be an inverted structure containing hydrocarbons at several levels: Top 
Latrobe, intra-Latrobe Group and Golden Beach Group (Sloan and others, 1992). The Golden Beach accumulation is sealed by a basalt flow and faulted against shale (Sloan and others, 1992).

\section{RESERVOIR ROCK}

The Latrobe Group sandstones are the primary reservoirs of the Gippsland Basin (Petroconsultants, 1996; McKerron and others, 1998; Thornton and others, 1980) with diagenesis an important factor in reservoir quality. Widespread dolomite cement, grain and cement solution secondary porosity development, illite, kaolinite and chlorite cement, and quartz overgrowths are all factors either occluding porosity or enhancing porosity. Dolomite cement occurs as pore filling and grain replacement and makes up as much as $30 \%$ of the total rock volume (Bodard and others, 1984). This widespread and variable cementation is the major cause of porosity reduction in the Latrobe Group.

Secondary porosity accounts for most of the reservoir porosity, principally as dissolution of dolomite cement that is possibly associated with hydrocarbon emplacement (Bodard and others, 1984). Dissolution of clay matrix is also a mechanism important in developing secondary porosity in the group (Bodard and others, 1984), as is dissolution of feldspars and rock fragments. Porosity may then be occluded by authigenic kaolinite growth, chlorite filling, quartz cementation and overgrowths, and compaction (Bodard and others, 1984). Porosity versus depth plots for Latrobe Group sandstone reservoirs of the Basker Manta area, suggest a severe decline in porosity approaching $4 \mathrm{~km}$ burial depth indicating a possible maximum depth of target reservoirs (Clark and Thomas, 1988). 


\section{SEAL ROCK}

Regionally extensive marine shales and marls of the Seaspray Group provide excellent seals for most of the fields in the area (Figs. 2, 4, and 6). Shales within the Latrobe Group provide seals for intra-Latrobe Group fields and a basalt flow provides the seal for at least one accumulation.

\section{UNDISCOVERED PETROLEUM BY ASSESSMENT UNIT}

Deeper, more marginal, and onshore prospects, as well as a shift to exploration for gas, may be the best targets of opportunity for future development of the petroleum resources in the Gippsland Basin Province (Megallaa, 1997; Mudge and Curry, 1992; Stainforth, 1984; Mehin and Bock, 1998; Collins, 1997; Collins and Megallaa, 1997). Producing horizons below the unconformity at the top of the Latrobe Group have been the most explored targets and that play is in its mature stage. Intra-Latrobe plays have become more attractive targets but there are variabilities of trap and migration to consider. Faults, for example, have been shown to act as seals in this basin, however, because of the nature of fluvial and shoreline sedimentary patterns, it is probably a rare circumstance to have a shale thick enough and in the right faulted position to act as a seal. Lateral facies changes also add a stratigraphic component to fault and rollover traps within the group and migration paths from the source areas may not encounter trapping structures.

Exploration targets down to the base of the Golden Beach Group, as well as within the Strzelecki Group, need to be considered around the margins of the basin. Possible source rocks of the Strzelecki Group are not well known from the subsurface but 
abundant thin coals are present in outcrop. These coals are projected to be thicker and more numerous in the subsurface. Although the source-rock quality of these coals is good and maturation and expulsion of hydrocarbons has been predicted (Mehin and Bock, 1998), there are uncertainties with regard to the timing of trap formation, continued integrity of traps, and the quality of potential Strzelecki Group reservoir rocks.

\section{REFERENCES}

Alexander, R., Kralert, P. G., Marzi, R., and Kagi, R. I., 1991, A geochemical method for assessment of the thermal histories of sediments: a two-well case study from the Gippsland Basin, Australia; The APEA Journal, v. 31, part 1, p. 325-332.

Bodard, J. M., Wall, V. J., and Cas. R. A. F., 1984, Diagenesis and the evolution of Gippsland Basin reservoirs; The APEA Journal, v. 24, part 1, p 314-335.

Bowen, R. L., and Thomas. G. A., 1976, Chapter 6, Permian, in Douglas, J. G., and Ferguson, J. A., eds., Geology of Victoria, Geological Society of Australia Special Publication No. 5, p. 125-142.

Bradshaw, M. T., Bradshaw, J., Weeden, R. J., Carter, P., and de Vries, D. F. H., 1998, Assessment - translating the future into numbers: APPEA Journal, 1998 -1 p. 528-551.

Bradshaw, M., 1993, Australian petroleum systems: PESA Journal, p. 43-53.

Burns, B. J., Bostwick, T. R., Emmett, J. K., 1987, Gippsland terrestrial oils-recognition of compositional variations due to maturity and biodegradation effects; The APEA Journal, v. 27, part 1, p. 73-84. 
Clark, A. B. S., Thomas B. M., 1988, The intra-Latrobe play: a case history from the Basker/Manta block (VIC/P19), Gippsland Basin; The APEA Journal, v. 28, part 1, p. 100-112.

Collins, G., 1997, Significant developments in Victoria; PESA News, April/May, Victorian Supplement, p.2.

Collins, G., and Megallaa, M., 1997, Optimising seismic in the onshore Gippsland Basin for deeper objectives; PESA News, April/May, Victorian Supplement, p. 13.

Douglas, J. G., 1976, Gippsland Basin; in Douglas, J. G., Abele, C., Benedek, S., Dettmann, M. E., Kenley, P. R., and Lawrence, C. R., Chapter 7, Mesozoic; in Douglas, J. G., and Ferguson, J. A., eds., Geology of Victoria, Geological Society of Australia Special Publication No. 5, p.158-176.

DPIE, 1998, Release of Offshore Petroleum Areas, Australia, 1998; Department of Primary Industries and Energy, Australia, $196 \mathrm{p}$ and CD-ROM.

Duff, B. A., Grollman, N. G., Mason, D. J., Questiaux, J. M., Ormerod, D. S., and Lays, P., 1991, Tectonostratigraphic evolution of the south-east Gippsland Basin; The APEA Journal, v. 31, part 1, p. 116-130.

Etheridge, M. A., Branson, J. C., and Stuart-Smith, P. G., 1987, The Bass, Gippsland and Otway Basins, southeast Australia: a branched rift system formed by continental extension, in Beaumont, Christopher, and Tankard, Anthony J., eds., Sedimentary Basins and Basin-Forming Mechanisms; Canadian Society of Petroleum Geologists Memoir 12, Atlantic Geoscience Society Special Publication 5, p. 147162. 
Falvey, David, A., and Mutter, John C., 1981, Regional plate tectonics and the evolution of Australia's passive continental margins; BMR Journal of Australian Geology and Geophysics, 6(1), p. 1-29.

Featherstone, P., Aigner, T., Brown, L., King, M., and Leu, W., 1991, Stratigraphic modeling of the Gippsland Basin; The APEA Journal, v. 31, part 1, p. 105-114.

Fielding, Christopher R., 1992, A review of Cretaceous coal-bearing sequences in Australia; in McCabe, Peter, J. and Parrish, Judith Totman, eds., Controls on the Distribution and Quality of Cretaceous Coals, Geological Society of America Special Paper no. 267, p. 303-324.

Gloe, C. S., with contributions from P. F. Bolger, J. G. Douglas, A. M. George, 1976, Brown coal; in Chapter 12, Economic Geology; in Douglas, J. G., and Ferguson, J. A., eds., Geology of Victoria, Geological Society of Australia Special Publication No. 5, p. 378-389.

Gross, M. D., 1993, Determination of reservoir distribution over the Blackback/Terakihi oil field, Gippsland Basin, Australia; APEA Journal, v. 33, part 1, p. 1-14.

Hart's E \& P, 1999, Bass Strait gas boom; December 1999, p 37.

Hill, Kevin C., Hill, Kathy A., Cooper, Gareth T., O’Sullivan, Andrea J., O’Sullivan, Paul B., and Richardson, M. Jane, 1995, Inversion around the Bass Basin, SE Australia, in Buchanan, J. G., and Buchanan, P. G., eds., Basin Inversion; Geological Society Special Publication no. 88, p. 525-547.

Hocking, J. B., with contributions from C. S. Gloe and W. F. Threlfall, 1976, Gippsland basin; in Abele, C., Gloe, C. S., Hocking, J. B., Holdgate, G., Kenley, P. R., Lawrence, C. R., Ripper, D., and Threlfall, W. F., Chapter 8, Tertiary; in Douglas, 
J. G., and Ferguson, J. A., eds., Geology of Victoria, Geological Society of Australia Special Publication No. 5, p. 248-273.

Howes, J. V. C., 1997, Petroleum resources and petroleum systems of SE Asia, Australia, Papua New Guinea, and New Zealand, in Howes, J. V. C., and Noble, R. A., eds., Proceedings of an International Conference on Petroleum Systems of SE Asia \& Australasia: Indonesian Petroleum Association, p. 81-100.

Keall, Jon M., and Smith, Mark A., 1996, The Golden Beach-Latrobe petroleum system, Gippsland Basin, Australia; American Association of Petroleum Geologists Annual Meeting Abstracts, p 73.

Knight, J. L., 1976, Black coal; in Chapter 12, Economic Geology; in Douglas, J. G., and Ferguson, J. A., eds., Geology of Victoria, Geological Society of Australia Special Publication No. 5, p. 373-378.

Lowry, D. C., 1987, A new play in the Gippsland Basin; The APEA Journal, v. 27, part 1, p. 164-172.

Lowry, D. C., and Longley, I. M., 1991, A new model for the mid-Cretaceous structural history of the Northern Gippsland Basin; The APEA Journal, v. 31, part 1, p 143153.

MacGregor, Duncan S., 1994, Coal-bearing strata as source rocks-a global overview; in Scott, A. C., and Fleet, A. J., eds., Coal and Coal-bearing Strata as Oil-prone Source Rocks?, Geological Society Special Publication No. 77, p. 107-116.

Marshall, Neil G., 1989, An unusual assemblage of algal cysts from the Late Cretaceous of the Gippsland Basin, southeastern Australia; Palynology, v. 13, p. 21-56. 
McCabe, Peter J., and Parrish, Judith Totman, 1992, Tectonic and climatic controls on the distribution and quality of Cretaceous coals, in McCabe, P. J., and Parrish, J. T., eds., Controls on the Distribution and Quality of Cretaceous Coals: Geological Society of America Special Paper 267, p. 1-15.

McCabe, Peter J., and Shanley, Keith W., 1992, Organic control on shoreface stacking patterns: Bogged down in the mire; Geology, v. 20, p. 741-744.

McKerron, A. J., Dunn, V. L., Fish, R. M., Mills, C. R., and van der Linden-Dhont, S. K., 1998, Bass Strait's Bream B reservoir development: success through a multifunctional team approach; APPEA Journal, v. 38, part 1, p. 13-34.

McPhee, I., including contributions from W. F. Threlfall, 1976, Oil and gas; in Chapter 12, Economic Geology; in Douglas, J. G., and Ferguson, J. A., eds., Geology of Victoria, Geological Society of Australia Special Publication No. 5, p. 395-403.

Mebberson, A. J., 1989, The future for exploration in the Gippsland Basin; The APEA Journal, v. 29, part 1, p 430-439.

Megallaa, M., 1997, Exploration opportunities in Gippsland Basin; PESA News, April/May, Victorian Supplement, p. 10-12.

Megallaa, Maher, 1993, Tectonic evolution of the Gippsland Basin and hydrocarbon potential of its lower continental shelf; The APEA Journal, v. 33, part 1, p. 45-61.

Mehin, K., and Bock, M. P., 1998, Cretaceous source rocks of the onshore Gippsland Basin, Victoria; Victoria Initiative for Minerals and Petroleum Report 54, 98 p..

Moore, P. S., Burns, B. J., Emmett, J. K., and Guthrie, D. A., 1992, Integrated source, maturation and migration analysis, Gippsland Basin, Australia; The APEA Journal, v. 32, part 1, p. 313-324. 
Mudge, W. J., and Curry, J. J., 1992, Development opportunities in the Kingfish and West Kingfish fields, Gippsland Basin; The APEA Journal, v. 32, part 1, p. 9-18.

Ozimic, S., Nicholas, E., Pain, L., and Vuckovic, V., 1987, Australian Petroleum Accumulations, Gippsland Basin, Victoria, Department of Primary Industries and Energy, Bureau of Mineral Resources, Geology and Geophysics, Canberra, 252 p.

Partridge, Alan D., 1996, Large break-up lakes of Bass Strait; Gippsland Basin Symposium, University of Melbourn, abstract, p. 3-6.

Petroconsultants, 1996, Petroleum Exploration and Production Database: Petroconsultants, Inc., P.O. Box 740619, 6600 Sands Point Drive, Houston TX 77274-0619, USA or Petroconsultants, Inc., P.O. Box 152, 24 Chemin de la Mairie, 1258 Perly, Geneva.

Philp, R. P., 1994, Geochemical characteristics of oils derived predominantly from terrigenous source materials; in Scott, A. C., and Fleet, A. J., eds., Coal and Coalbearing Strata as Oil-prove Source Rocks?, Geological Society Special Publication No. 77, p.71-91.

Rahmanian, V. D., Moore, P. S., Mudge, W. J., and Spring, D. E., 1990, sequence stratigraphy and the habitat of hydrocarbons, Gippsland Basin, Australia; in Brooks, J., ed., Classic Petroleum Provinces, Geological Society Special Publication No. 50, p 525-541.

Sloan, M. W., 1987, Flounder-a complex intra-Latrobe oil and gas field; The APEA Journal, v. 27, part 1, p. 308-317.

Sloan, M. W., Moore, P. S., and McCutcheon, A., 1992, Kipper-a unique oil and gas discovery, Gippsland Basin, Australia; The APEA Journal, v. 32, part 1, p. 1-8. 
Smith, G. C., and Cook, A. C., 1984, Petroleum occurrence in the Gippsland Basin and its relationship to rank and organic matter type; The APEA Journal, v. 24, part 1, p. 196-216.

Stainforth, J. G., 1984, Gippsland Hydrocarbons-A Perspective from the Basin Edge; APEA Journal, v. 24, part 1, p. 91-100.

Thornton, R. C. N., Burns, B. J., Khurana, A. K., and Rigg, A. J., 1980, The Fortescue Field—new oil in the Gippsland Basin; The APEA Journal, v. 20, part 1, p. 130142.

World Oil, 1997, Australia leads a revival; World Oil, August 1997, p 183-187. 


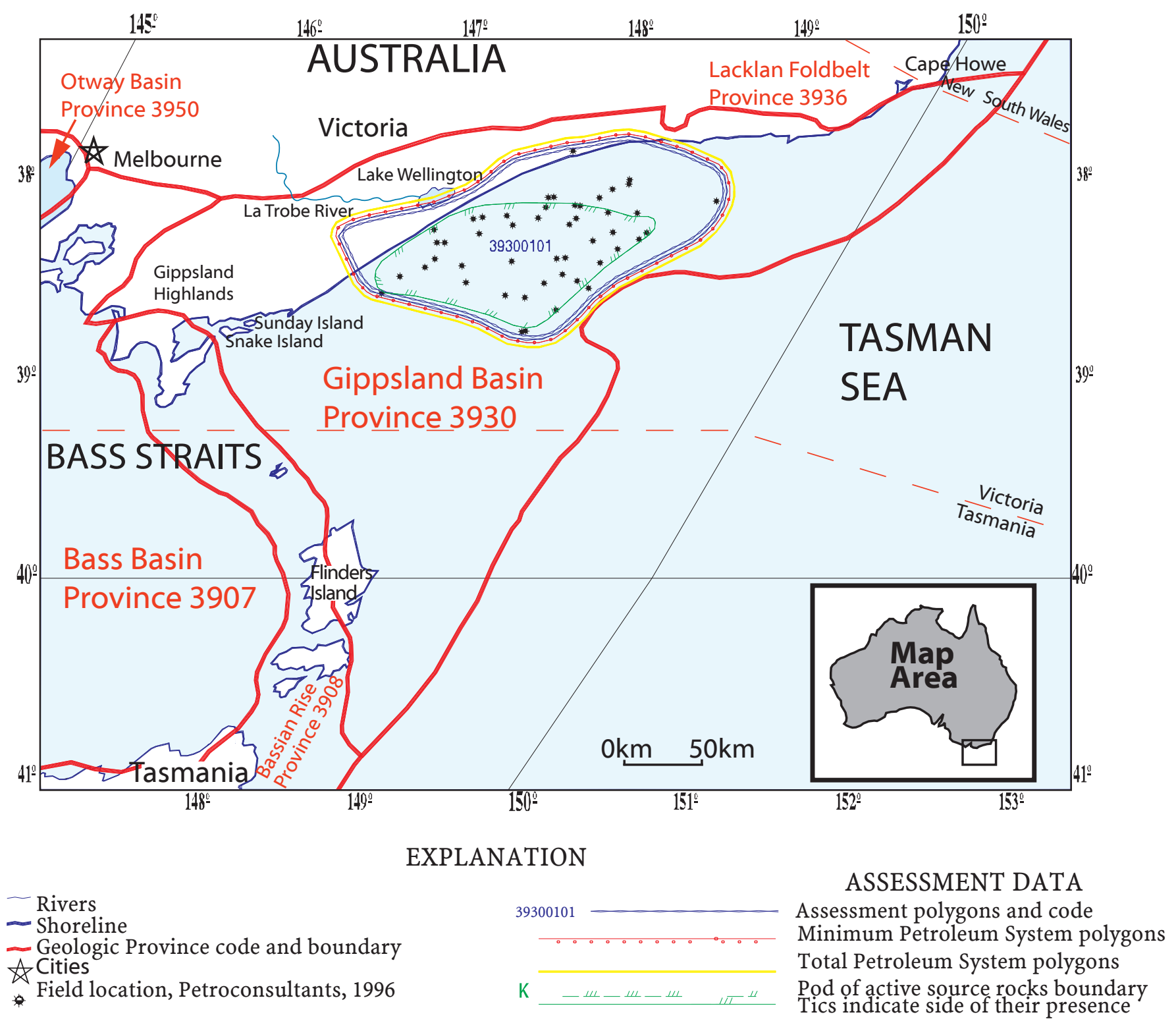

Figure 1. Index map of Gippsland Basin Province 3930, Australia. The basin is located onshore and offshore in the northern half of the province. There is one total petroleum system, Latrobe (393001), with one assessment unit, Gippsland (39300101) shown. 


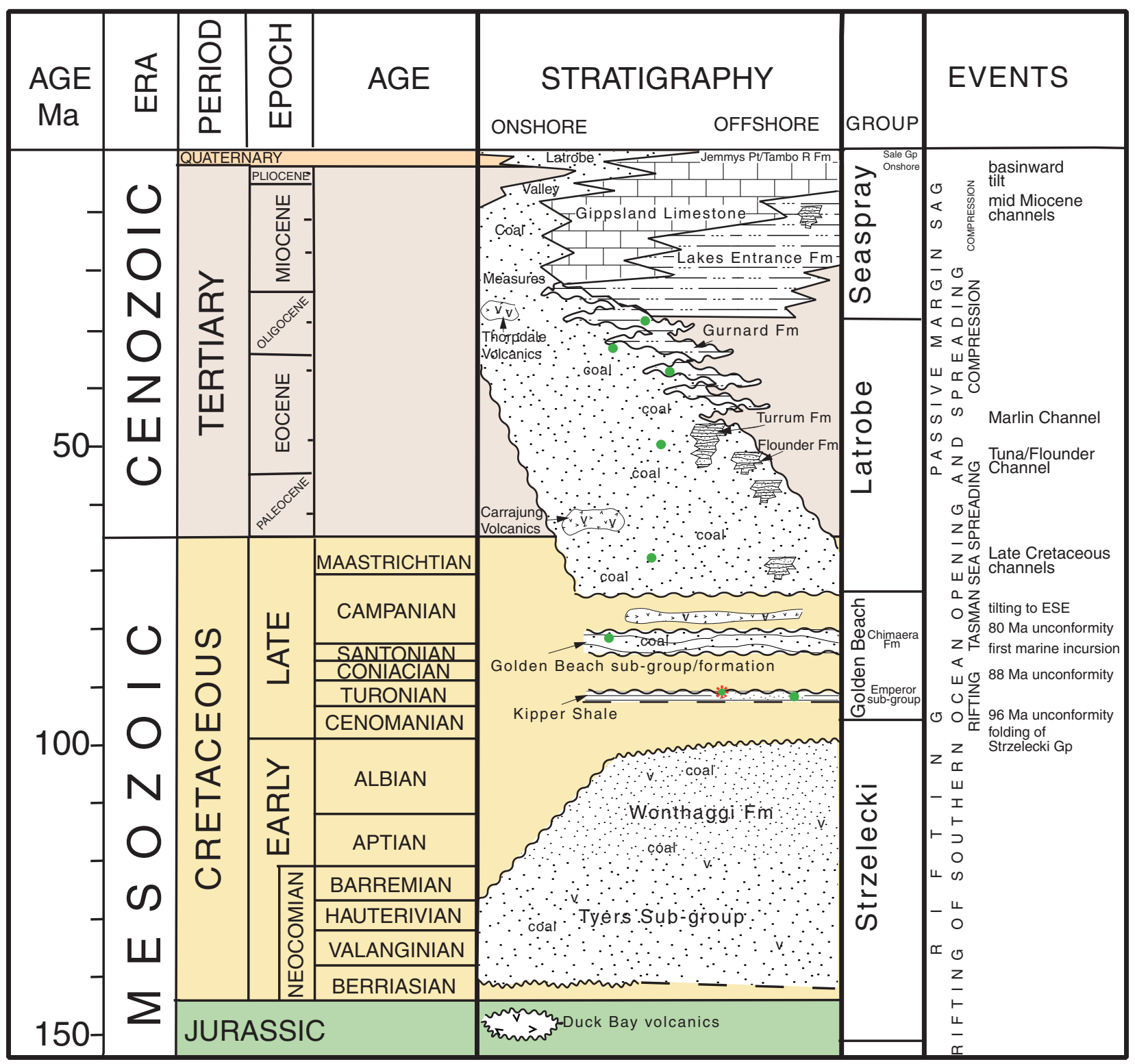

Figure 2. Stratigraphic column of the Gippsland Basin, Australia. Major depositional groups, sub-groups and formations are shown where they have been named. For detailed onshore stratigraphy see Douglas (1976). Possible source-rock coals are in the Strzelecki Group and throughout the Latrobe Group. Coals of the Golden Beach sub-group and of the Upper Cretaceous and Paleocene Latrobe Group are most likely to be mature and generating hydrocarbons. Major tectonic events are shown as well as periods of channeling important for trap formation. The regional seal is the Seaspray Group in addition to intraformational seals. The Kipper Shale is of lacustrine origin. Hydrocarbons in fault blocks on the edge of the basin in Turonian age sandstones are sealed by volcanics. Compiled from Partridge (1996), Mebberson (1989), Mehin and Bock (1998) DPIE (1998), Stainforth (1984), Lowry and Longley (1991), Rahmanian and others (1990). 


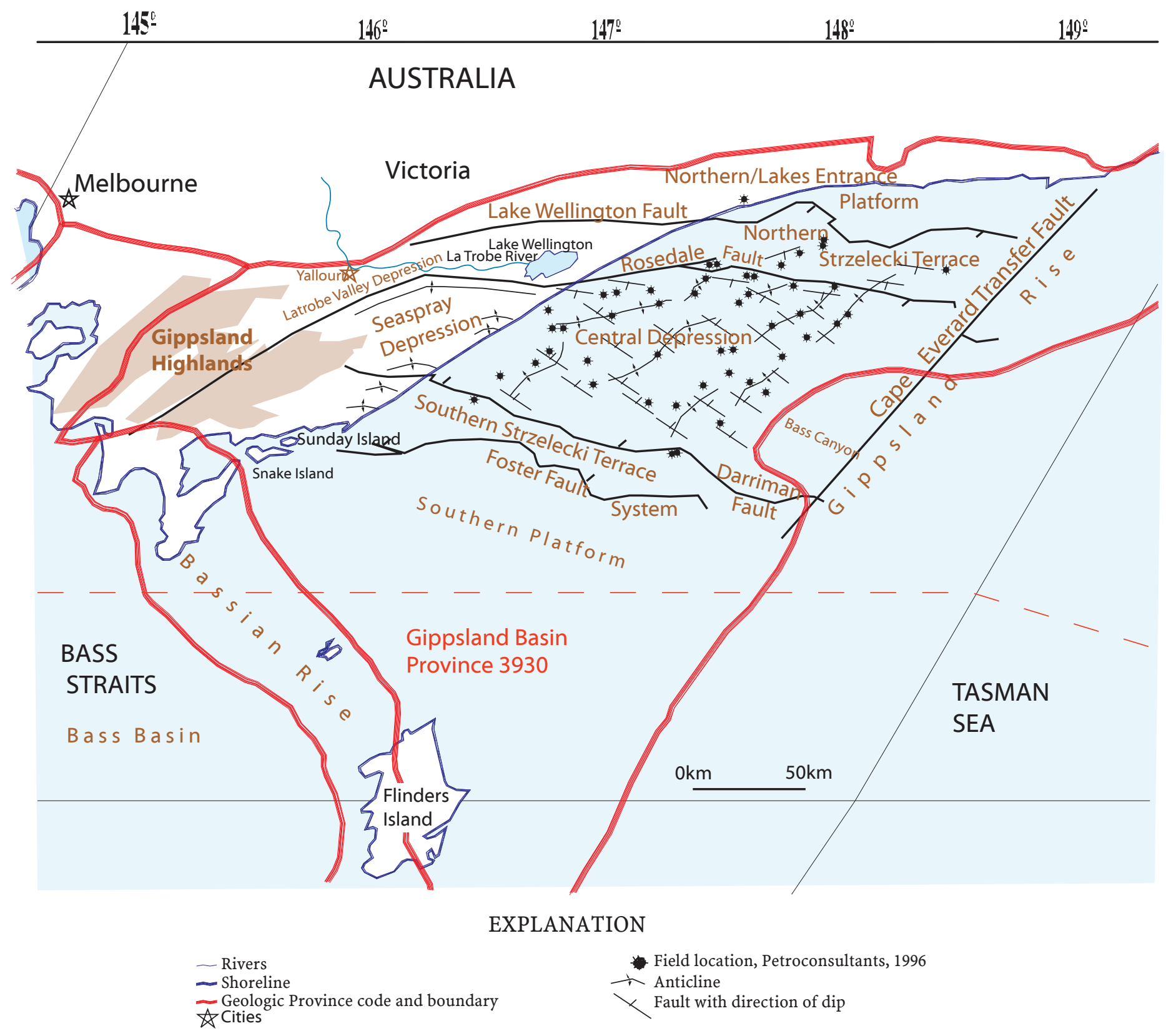

Figure 3. Gippsland Basin Province 3930 map showing generalized structural features. The Gippsland Highlands are comprised of outcrops of the Strzelecki Group. The depositional limit of the Strzelecki Group is roughly the Foster fault system and the Lake Wellington fault. The depositional limit of the Latrobe Group is roughly the Rosedale fault and the Darriman fault. Major offshore anticlines trend north-south and faults trend generally east-west (assembled from various sources: DPIE, 1998; Mehin and Bock, 1998; Megallaa, 1993; Abele and others, 1976; Ozimic, 1987; Rahmanian and others, 1990). 

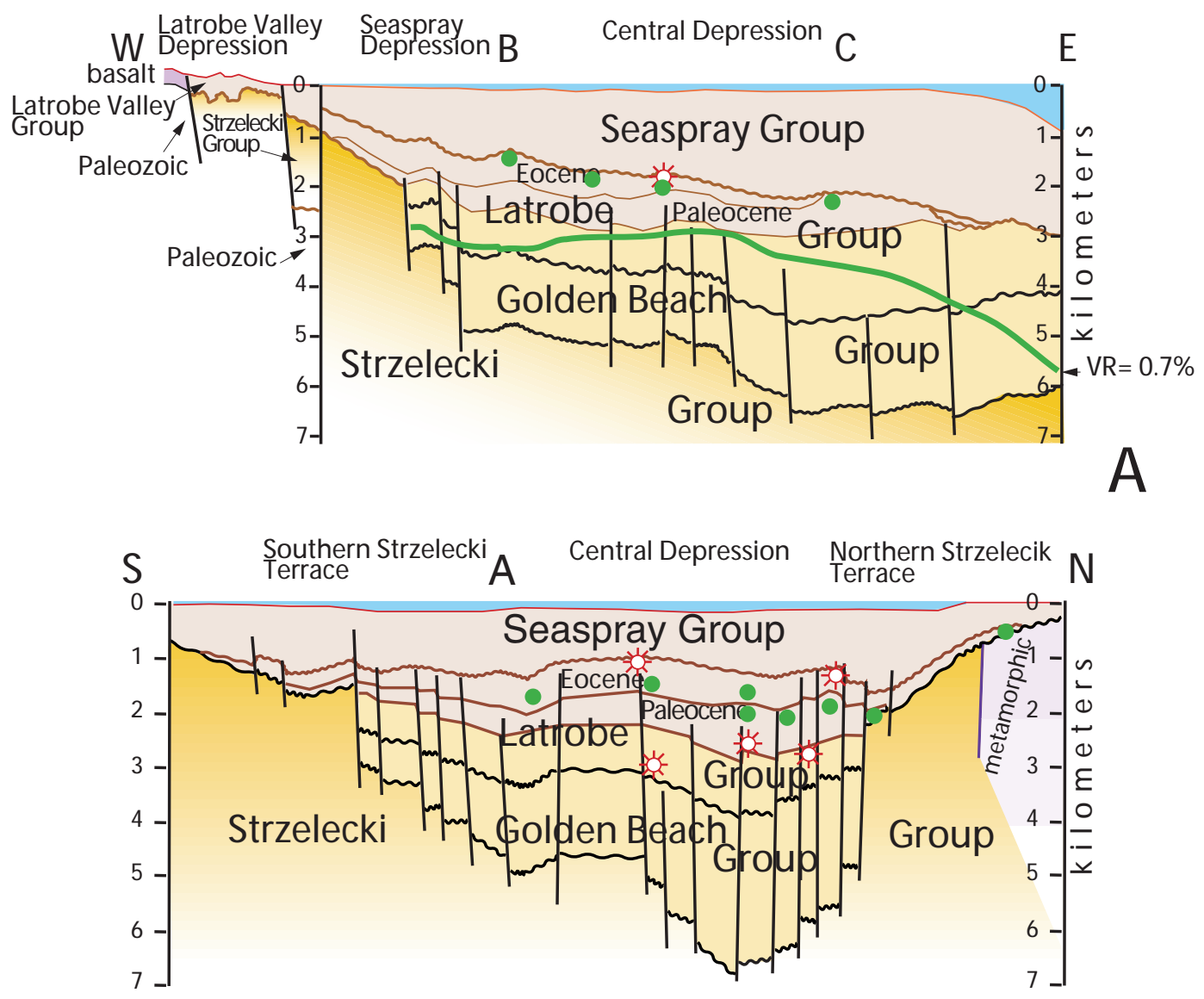

B

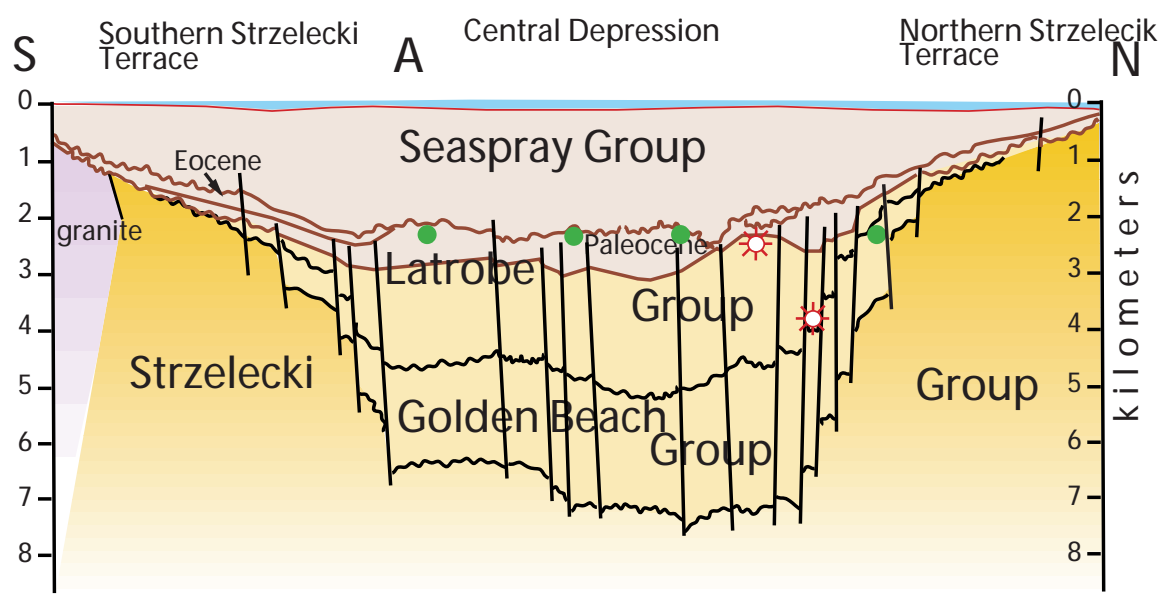

Figure 4. Generalized cross sections of Gippsland Basin Province 3930 located on figure 5. Shown are the levels of major hydrocarbon fields the vitrinite reflectance (VR or Ro) $=0.7 \%$ level, and the intersection of the cross sections. No horizontal scale. Modified from Rahmanian and others (1990) and Able and others (1976). 


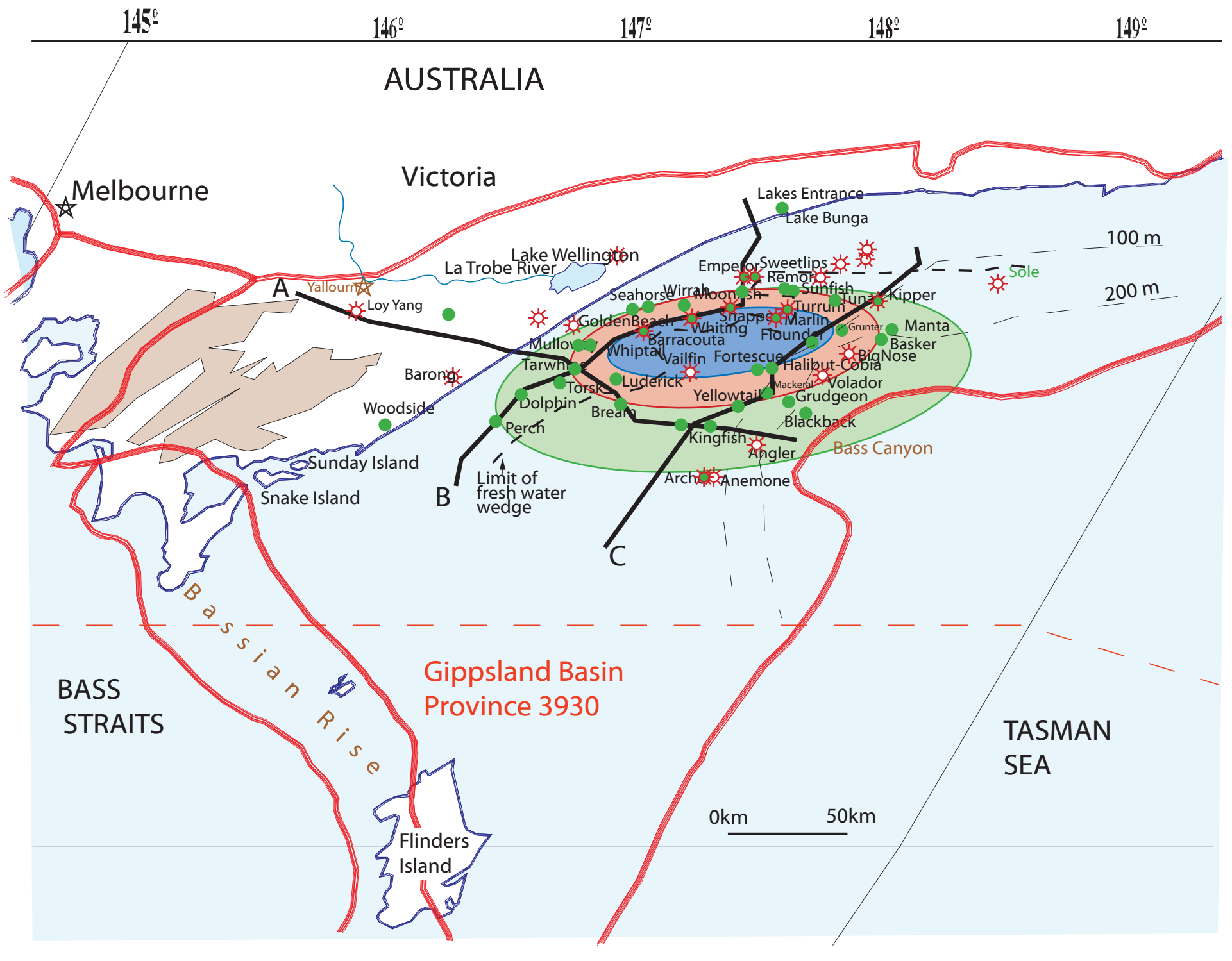

\section{EXPLANATION}

- Rivers

Shoreline

- Geologic Province code and boundary
$\Varangle$ Cities

Field locations, other shows

㨁- and discoveries, oil and gas

Figure 5. Gippsland Basin Province 3930 showing important fields and discoveries. The generalized areas of levels of maturation in the basin of the lower Latrobe Group are shown in green, mature for oil; red, mature for gas and oil; and purple, overmature. Also shown are the approximate locations of the eastern edge of the fresh-water wedge and bathymetry at 100 and 200 meters. Modified from Rahmanian and others (1990), Moore and others (1992). 


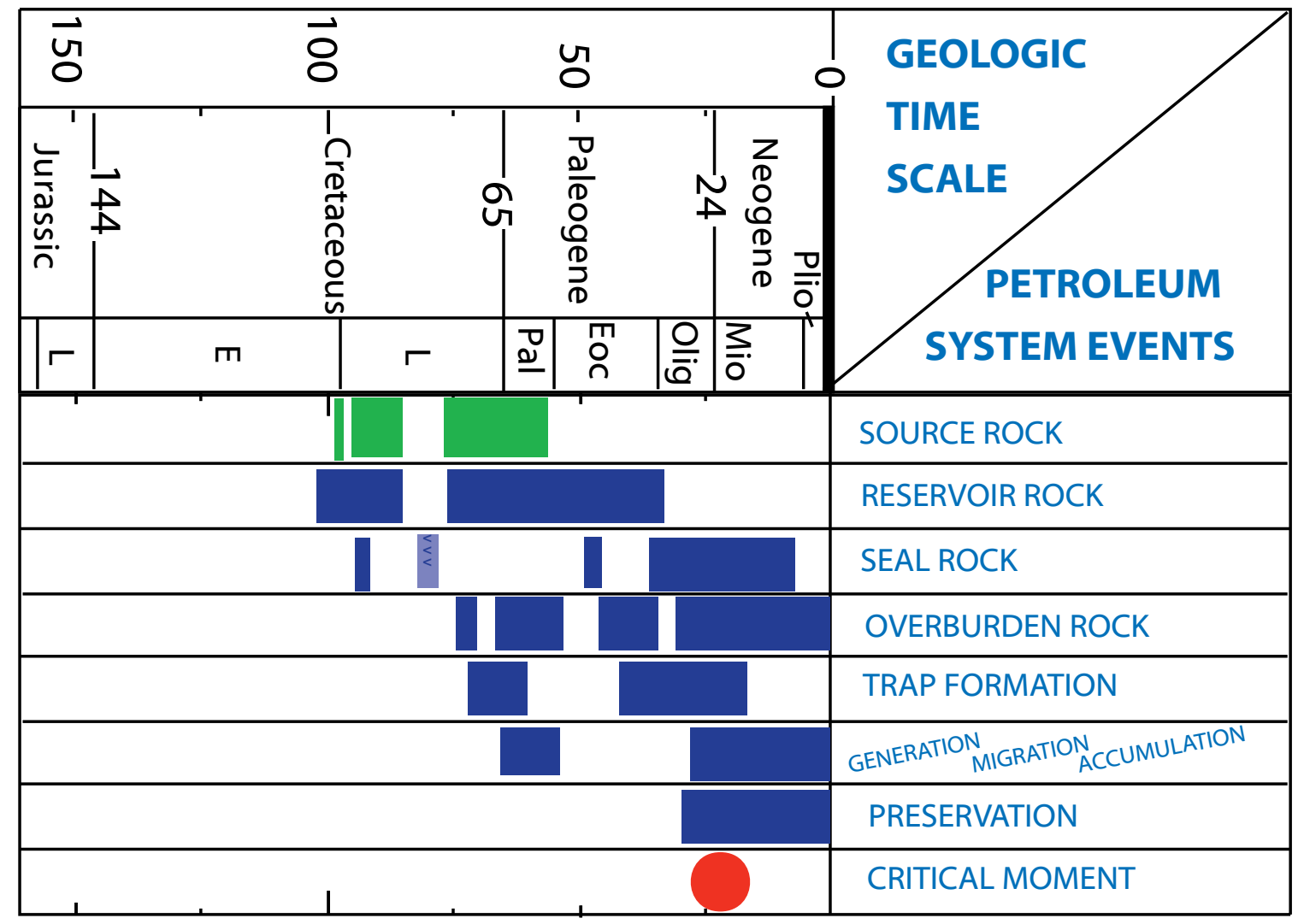

Figure 6. Timing and events of the Latrobe Total Petroleum System, Gippsland Basin Province 3930. 